\title{
EFFECT OF AGE ON TIME-COMPRESSED SPEECH PERCEPTION AND SPEECH PERCEPTION IN NOISE IN NORMAL-HEARING INDIVIDUALS
}

\author{
Prawin Kumar, Biswajit Pradhan, Deeksha Handa, Himanshu Kumar Sanju \\ Department of Audiology, All India Institute of Speech and Hearing, Mysore, India \\ Corresponding author: Himanshu Kumar Sanju, Department of Audiology, All India Institute of Speech and \\ Hearing, Mysore, India, e-mail: himanshusanjuaiish@gmail.com
}

\begin{abstract}
Background: This work studied, in individuals with normal hearing, the perception of time-compressed speech, compression ratio, and speech perception in noise using phonemically balanced (PB) word lists in Kannada. The effect of age was also studied.

Materials and Methods: Participants were 29 young and middle-aged adults (native Kannada speakers) aged 15 to 50 years. The Speech Perception in Noise (SPIN) test was administered at signal to noise ratios (SNRs) of $+5 \mathrm{~dB}, 0 \mathrm{~dB},-5 \mathrm{~dB}$, and in quiet. The Time-Compressed Speech Test (TCST) was administered on all participants at compression ratios of $0 \%, 40 \%, 50 \%$, and $60 \%$.

Results: Young adults performed better than middle-aged adults in both the TCST and SPIN tests. As difficulty levels rose, performance decreased in both tests.

Conclusions: Even in individuals with normal hearing, ageing has a deleterious effect on the performance of the central auditory processing system, which is necessary for speech perception under adverse listening conditions.

Key words: compression ratio $\bullet$ speech perception $\bullet$ ageing $\bullet$ monoaural low redundancy $\bullet$ Kannada

\section{IMPACTO DE LA EDAD EN LA PERCEPCIÓN DEL HABLA COMPRIMIDO EN EL TIEMPO Y LA PERCEPCIÓN DEL HABLA EN RUIDO EN PERSONAS CON AUDICIÓN NORMAL}

\section{Resumen}

Introducción: Este estudio analiza la percepción del habla comprimido a través del tiempo en personas con audición normal, y también la relación de esta compresión y la percepción del habla en ruido, usando listados de palabras fonéticamente equilibradas (PB) en el idioma kannada. También se ha analizado el impacto del factor de la edad.

Materiales y métodos: El grupo del estudio- estaba compuesto de 29 personas jóvenes y personas de mediana edad (cuya lengua materna es el idioma kannada) - edad de 15 a 50 años. Se ha realizado la prueba de la compresión del habla en ruido (SPIN) para la relación de señal - ruido (SNR) $+5 \mathrm{~dB}, 0 \mathrm{~dB},-5 \mathrm{~dB}$, y en el silencio. La prueba de comprensión del habla comprimido en el tiempo (SNR). La prueba de la comprensión del habla comprimido en el tiempo (TCST) ha sido realizado en todos los participantes de la prueba para una relación de compresión de $0 \%, 40 \%, 50 \%$, i $60 \%$.

Resultados: Los jóvenes han logrado un resultado mejor que las personas de mediana edad en ambas pruebas, TCST y SPIN. Los resultados iban deteriorando en paralelo al incremento de la dificultad en ambas pruebas.

Conclusiones: Incluso en personas con audición normal, la edad tiene un impacto negativo en el funcionamiento del procesamiento auditivo central, que es necesario para entender el habla en las condiciones auditivas desfavorables.

Palabras clave: relación de compresión • percepción del habla • envejecimiento • redundancia monofónica baja • idioma kannada 


\section{ВЛИЯНИЕ ВОЗРАСТА НА ВОСССПРИЯТИЕ РЕЧИ, КОМПРЕССИРОВАННОЙ ВО ВРЕМЕНИ И ВОСПРИЯТИЕ РЕЧИ В ШУМЕ У ЛЮДЕЙ С НОРМАЛЬНЫМ СЛУХОМ}

\section{Изложение}

Введение: Настоящая работа исследует восприятие речи, компрессированной во времени у людей с нормальным слухом, а также коэффициент компрессии и восприятие речи в шуме с использованием словных, фонетически сбалансированных списков (РВ) на языке каннада. Проанализировано также влияние возраста.

Материал и методы: Исследованная группа состояла из 29 молодых людей и людей среднего возраста (родным языком которых является язык каннада) - возраст: 15-50 лет. Проведен тест понимания речи в шуме (SPIN) для отношения сигнал/ шум SNR) $+5 \mathrm{~dB}, 0 \mathrm{~dB},-5 \mathrm{~dB}$, а также в тишине. Тест понимания речи, компрессированной во времени (TCST) был проведен у всех участников исследования для коэффициента компрессии - 0\%, $40 \%, 50 \%$, и $60 \%$.

Результаты: Молодые люди получили лучшие результаты чем люди среднего возраста в обоих тестах TCST и SPIN. Результаты ухудшились вместе с возрастанием трудностей в обоих тестах.

Итоги: Даже у людей с нормальным слухом возраст имеет отрицательное влияние на функционирование центральной системы слуховой переработки, которая является необходимой для понимания речи в неблагоприятных слуховых условиях.

Ключевые слова: коэффициент компрессии • воссприятие речи • старение, монофоническая низкая редунданция, язык каннада

\section{WPŁYW WIEKU NA PERCEPCJE MOWY SKOMPRESOWANEJ W CZASIE I PERCEPCJE MOWY W SZUMIE U OSÓB Z NORMALNYM SŁUCHEM}

\section{Streszczenie}

Wprowadzenie: Niniejsza praca bada percepcję mowy skompresowanej w czasie u osób z normalnym słuchem, a także stosunek kompresji i percepcję mowy w szumie przy użyciu list słownych zbalansowanych fonetycznie (PB) w języku kannada. Analizowano także wpływ wieku.

Materiał i metody: Grupa badana składała się z 29 młodych osób oraz osób w średnim wieku (których językiem ojczystym jest kannada) - wiek 15 do 50 lat. Przeprowadzono test rozumienia mowy w szumie (SPIN) dla stosunku sygnału do szumu $(\mathrm{SNR})+5 \mathrm{~dB}, 0 \mathrm{~dB},-5 \mathrm{~dB}$, oraz w ciszy. Test rozumienia mowy skompresowanej w czasie (TCST) wykonano u wszystkich uczestników badania dla stosunku kompresji wynoszącego $0 \%, 40 \%, 50 \%$, i $60 \%$.

Wyniki: Osoby młode uzyskały lepszy wynik niż osoby w średnim wieku w obu testach TCST i SPIN. W miarę wzrostu trudności w obu testach, wyniki pogarszały się.

Wnioski: Nawet u osób z normalnym słuchem, wiek ma negatywny wpływ na działanie centralnego układu przetwarzania słuchowego, który jest niezbędny do rozumienia mowy w nieprzyjaznych warunkach słuchowych.

Słowa kluczowe: stosunek kompresji • percepcja mowy • starzenie się • monofoniczna niska redundancja • język kannada

\section{Background}

The performance of older subjects in understanding speech has been studied extensively. Various studies have reported that, with advancing age, speech recognition performance does not change significantly under quiet conditions $[1,2]$ but suffers significantly under adverse listening conditions $[3,4]$. Research has found that middle-aged and older adults perform poorer than younger subjects on a speech recognition task when some of the speech content is filtered out $[5,6]$. In the presence of noise, older subjects need up to a $4 \mathrm{~dB}$ greater signal to noise ratio than younger subjects to perform similarly [7]. For normal speech perception, auditory temporal resolution is an important parameter $[8,9]$. Psychophysical studies have indicated a decline in various auditory abilities, including auditory temporal processing, in middle-aged and older subjects [10,11]. Letowski and Poch (1996) assessed time-compressed speech in older and middle aged adults [12]. They reported that older adults were affected more 
by compression ratio values than were middle-aged adults. Another study done by Versfeld and Dreschler (2002) also reported poorer performance in older individuals for time-compressed speech compared to younger individuals [13]. Similarly, Jafari et al. (2013) also investigated the effect of age on time-compressed speech and reported that age greatly affected the processing of fast speech stimuli and decreased temporal resolving ability [14]. For tests of recognition of time-compressed speech, in which the rates of presentation are increased by using sampling methods (either through digital or mechanical techniques), an age-related decline is considered the most important factor $[12,15]$. An older person's ability to label chunks of acoustic information, process it serially, and derive meaning within a brief period of time is challenged by a decline in processing rate.

Many researchers have shown that a reduction in the speech-perception performance of middle-aged subjects is due to age-related changes in peripheral hearing sensitivity $[4,16]$. However, other investigators have shown that, in addition to a deterioration in hearing sensitivity, there is a central involvement $[3,17]$. The central auditory system has also been suggested as causing complications in understanding speech under unfavorable listening conditions despite there being essentially normal peripheral hearing sensitivity $[18,19]$.

Many researchers have reported that the auditory system continues to deteriorate, both physiologically and anatomically, throughout the lifespan, with a particular acceleration beginning in middle age (from 40 years of age) [20,21]. Damage to both inner and outer hair cells has been reported after the age of 45 years [20], whereas for subjects above the age of 60 , degeneration was widespread in all cochlear turns [21]. Progressive atrophy of the stria vascularis has also been observed throughout the lifespan, and accelerates after 50 years of age [22].

There are indications that, compared to young listeners, individuals of middle-age and older have greater difficulty in understanding speech as compression ratio and noise level increases $[13,15,23,24]$. The time-compressed speech test (TCST) and the speech in noise (SPIN) test are common monaural low redundancy tests. There are only a few studies which have focused on both these tests. A study by Versfeld and Dreschler evaluated speech intelligibility in young (20 to 29 years) and older (58 to 70 years) individuals using TCST and SPIN; overall, they reported that elderly listeners performed poorly in comparison to the younger listeners [13]. Another study by Prabhu et al. (2015) also reported that, as compression ratio increased, speech recognition scores reduced. Indirectly, it indicates that individuals can hear better at lower compression levels [24]. A study by Vaughan and Letowski (1997) reported poorer performance for older people compared to young and middle-aged individuals [15].

There are more studies which have focused on TCST and SPIN independently $[8,13,24]$. However, very few studies have tried to check the relationship between the two different tests in terms of auditory closure ability [15]. Since both the tests assess the same domain in spite of differences in the nature of the stimulus, in the current study the speech material used was in the Kannada language. Kannada is a Dravidian language spoken predominantly by people in south India and rates $27^{\text {th }}$ as the most widely spoken language. The language uses 49 phonemic letters divided into three groups: Swaragalu (13 letters), Yogavaahakagalu (2 letters), and Vyanjanagalu (34 letters), broadly similar to vowels and consonants [25]. Venkatesh (1995) [26] investigated the effect of the consonant $/ \mathrm{k} /$ on vowel duration of all the vowels in the Kannada language. The result showed that each vowel in Kannada had its own intrinsic duration, the vowel duration varying with the height of the tongue. They also observed that the openness or closeness of vowels also affected the duration of the vowel, and rounded vowels had shorter vowel duration compared to unrounded vowels. Their study also revealed that the duration of long vowels were approximately twice that of short vowels, and these short and long vowels had different relationships to their respective word durations and syllable durations. According to Savithri (1989) [27], four types of stops are possible in Kannada: viz. voiceless aspirated (kh, țh, th, ph), voiceless unaspirated $(k, t, t, p)$, voiced murmured ( $\mathrm{gh}, \mathrm{dh}, \mathrm{dh}, \mathrm{bh}$ ), and voiced unaspirated ( $g, d, d, b)$. In Kannada, dentals have maximum closure duration, followed by bilabials, velars, and retroflexes. Voice Onset Time (VOT) for voiced stops ranges from 0 to $25 \mathrm{~ms}$, in contrast with English stop consonants where VOT is a cue to differentiate voiced from voiceless. VOTs greater than $25 \mathrm{~ms}$ are perceived as voiced in English. In Kannada, $/ \mathrm{c} /, / \mathrm{ch} /, / \mathrm{j} /$, and $/ \mathrm{jh} /$ are the four affricatives of which the first two are voiceless and the remaining are voiced. Kannada has four fricatives: the palatal /s'/, the retroflex /s /, the dental /s/, and the glottal partially voiced /h/. It has been found that in Kannada a listener identifies an emotion as surprise if the final contour is a rise or a fall. The present study investigated, in Kannada individuals with normal hearing, the deleterious effect of age in terms of the time-compressed speech test and the speech perception in noise. Another aspect to be explored was to find out which test was more sensitive to closure deficit in each age group.

\section{Material and methods}

\section{Participants}

Two groups of subjects participated in the study. Group I, the control group, consisted of 15 right-handed young adults ( 8 females and 7 males) aged 18 to 25 years (mean 22.35) from a government science college. Group II, the experimental group, consisted of 14 right-handed middleaged adults ( 7 males and 7 females) of age 30 to 50 years (mean 44.62). Informed oral and written consent was taken from all participants. The study was approved by the ethical committee at the All India Institute of Speech and Hearing, Mysore.

\section{Participant selection criteria}

All subjects had normal hearing thresholds as defined by pure tone thresholds of $<15 \mathrm{dBHL}$ at 500,1000, 2000, 4000, and $8000 \mathrm{~Hz}$. Additionally, all participants had normal middle ear function as revealed by a type A tympanogram and the presence of acoustic reflexes at 500,1000, 2000, and $4000 \mathrm{~Hz}$ ipsilaterally and contralaterally. They 
also had at least a fair agreement (less than $\pm 6 \mathrm{~dB}$ ) between speech recognition threshold (SRT) and pure-tone average. An additional criterion for participation in both groups was a word recognition score (WRS) in excess of $90 \%$ in quiet. No participant had any presence or history of otological or neurological problems.

\section{Instrumentation}

A calibrated dual channel diagnostic audiometer (GSI 61) with supra-aural headphones (TDH-39) was used to obtain air-conduction thresholds. The same audiometer with a Radioear B-71 bone-vibrator was used for bone-conduction thresholds. A calibrated immittance audiometer (GSI Tympstar) was used for tympanometry and reflexometry.

\section{Procedure}

Pure tone thresholds were obtained using a modified version of the Hughson and Westlake procedure (Carhart \& Jerger, 1959) to establish normal hearing sensitivity [28]. Air conduction thresholds were obtained for octave frequencies between $250 \mathrm{~Hz}$ and $8 \mathrm{kHz}$ and bone conduction thresholds were measured at octave frequencies between $250 \mathrm{~Hz}$ and $4 \mathrm{kHz}$. To rule out middle ear pathology, immittance audiometry and reflexometry were carried out. Immittance audiometry was done using a $226 \mathrm{~Hz}$ probe tone; reflexometry included obtaining ipsilateral and contralateral acoustic reflexes at 500,1000, 2000, and $4000 \mathrm{~Hz}$ with the same $226 \mathrm{~Hz}$ probe tone.

\section{Time-compressed speech test}

The time-compressed speech test (TCST) in Kannada is the compressed form (Kumar and Yathiraj, 2006) of the Kannada phonemically balanced (PB) word list. The PB word list was used in a TCST at a compression ratio of $0 \%, 40 \%$, $50 \%$, and $60 \%$ [29]. The stimuli from the "Bisyllabic Phonemically Balanced Words in Kannada for Children" developed by Yathiraj and Vijyalakshmi (2005) [30] was used to prepare the compressed material. This test consisted of four lists each having 25 Kannada bisyllabic words which were phonemically balanced. The lists were reported to be equal in terms of phonemic balance as well as perceptual difficulty. A recorded version of the test was used; the lists were recorded by a female native speaker of Kannada using Creative Wave Studio software and compressed using Praat by $0 \%, 40 \%, 50 \%$, and $60 \%$. A $1 \mathrm{kHz}$ calibration tone was recorded before each list for adjusting the VU meter of the audiometer. The output of the computer was recorded onto an audio $\mathrm{CD}$, and the prerecorded compressed speech was played into the audiometer. Participants were instructed about listening to compressed speech before testing. In this test the speech stimulus (PB words) with noise was presented through headphones to the right ear in $50 \%$ of subjects and to the left ear in the other $50 \%$ (to control for 'ear effect'). The participants were instructed to give a written response, and the responses were later statistically analysed.

\section{Speech perception in noise test}

The testing was done at quiet and various signal to noise ratios (SNRs). To adjust SNR to $0 \mathrm{~dB},+5 \mathrm{~dB}$, and $-5 \mathrm{~dB}$, speech level was kept constant at $40 \mathrm{dBHL}$ and the level of noise was varied, i.e. 40,35 , and $45 \mathrm{dBHL}$ respectively. The PB word list with 25 words was used as a reference. For both the tests, i.e. TCST and SPIN, the stimuli were routed from the computer to the input of an Inventis diagnostic (Padova, Italy) audiometer and TDH-50 headphones with MX-41/AR cushions. The presentation level was at $40 \mathrm{dBSL}$ (re: speech recognition threshold). Speech identification scores were determined for each compression ratio for both stimuli. The participants again gave a written response. The participants were asked to guess the speech items if they were not clear. The stimuli presentation was randomized for all lists to avoid practice and order effects. For the SPIN test, the noise detection threshold was first obtained for each individual and considered as a reference for presentation of noise levels. The test was administered at four different SNRs, i.e. $+5 \mathrm{~dB}, 0 \mathrm{~dB},-5$ $\mathrm{dB}$, and in quiet. To avoid ear effect, SPIN was administered in the right ear to $50 \%$ of subjects and to the left ear for the other $50 \%$.

\section{Data analysis}

The correct responses were calculated for both stimuli for all ratios and converted to percentage scores. Statistical analysis was carried out using SPSS version 21 . Descriptive statistics and mixed analysis of variance (ANOVA) were used to analyze the data.

\section{Results}

Descriptive statistics showed higher (better) means for young adults compared to middle-aged adults for both SPIN and TCST, as shown in Tables 1 and 2 respectively. Performance was better in quiet and at $0 \%$ compression ratio in comparison to SNRs of $+5 \mathrm{~dB}, 0 \mathrm{~dB}$, and $-5 \mathrm{~dB}$ ) and at higher compression ratios of $40 \%, 50 \%$, and $60 \%$.

Repeated measure ANOVA was done to see the effect of SNR between the two groups. Results of the SPIN test showed significant main effects for $\operatorname{SNR}[F(3,81)=14.81 ; p<0.001$; $\eta^{2}=0.354$; Type III SS $=250.14$; mean square $\left.=83.38\right]$. However, there was no interaction with two groups at different SNRs $\left[F(3,81)=0.38 ; p>0.05 ; \eta^{2}=0.013\right]$. When the two groups were compared, results showed marginally significant differences $\left[F\left(1,27=3.59 ; p<0.06 ; \eta^{2}=0.117\right.\right.$; Type III $\mathrm{SS}=102.22$; mean square $=102.22$ ]. The standard deviation of the total data was 4.20 . Figure 1 shows the outcomes.

Similarly, repeated measure ANOVA was done to see how age affected TCST outcomes. Results showed significant main effects for compression ratio $(0 \%, 40 \%, 50 \%$, and $60 \%)\left[F(3,81)=9.15 ; p<0.001 ; \eta^{2}=0.253\right.$, Type III SS=104.79; mean square $=34.93]$. However, there was no interaction with two groups at different SNRs $[F(3,81)=0.09 ; p>0.05$; $\left.\eta^{2}=0.074\right]$. When the two groups were compared, results showed marginally significant differences $[F(1,27)=3.64$; $p<0.06 ; \eta^{2}=0.119$; Type III SS=93.60; mean square=93.60]. The standard deviation of the total data was 4.38 . Figure 2 shows the results graphically. The present study clearly shows that in both tests the performance was poorer as the difficulty level increased. 
Kumar et al. - Effect of age on time-compressed speech perception and speech perception in noise...

Table 1. Mean and standard deviation (SD) of SPIN in young and older adults at different SNRS

\begin{tabular}{ccccc}
\hline Groups & $\begin{array}{c}\text { Quiet } \\
\text { Mean (SD) }\end{array}$ & $\begin{array}{c}+5 \mathrm{~dB} \text { SNR } \\
\text { Mean (SD) }\end{array}$ & $\begin{array}{c}\text { 0 dB SNR } \\
\text { Mean (SD) }\end{array}$ & $\begin{array}{c}\mathbf{- 5} \mathrm{dB} \text { SNR } \\
\text { Mean (SD) }\end{array}$ \\
\hline Young adults & $23.85(1.56)$ & $22.42(3.71)$ & $22.14(3.18)$ & $20.28(4.53)$ \\
\hline Older adults & $22.66(2.49)$ & $20.66(2.94)$ & $19.86(3.92)$ & $18.00(3.68)$ \\
\hline
\end{tabular}

Standard deviation of total data=4.20; $F=3.59 ; p<0.06 ; \eta^{2}=0.117$; Type III SS=102.22; mean square=102.22.

Table 2. Mean and standard deviation (SD) of TCST in young and older adults at different compression ratios

\begin{tabular}{ccccc}
\hline Groups & $\begin{array}{c}\mathbf{0 \%} \text { CR } \\
\text { Mean (SD) }\end{array}$ & $\begin{array}{c}\mathbf{4 0 \%} \text { CR } \\
\text { Mean (SD) }\end{array}$ & $\begin{array}{c}\mathbf{5 0 \% ~ C R} \\
\text { Mean (SD) }\end{array}$ & $\begin{array}{c}\mathbf{6 0 \%} \text { CR } \\
\text { Mean (SD) }\end{array}$ \\
\hline Young adults & $23.78(2.00)$ & $23.78(1.76)$ & $22.42(3.83)$ & $22.85(4.01)$ \\
\hline Older adults & $23.26(1.83)$ & $22.13(1.99)$ & $20.53(3.27)$ & $19.73(4.28)$ \\
\hline
\end{tabular}

Standard deviation of total data=4.38; $F=3.64 ; p<0.06 ; \eta^{2}=0.119 ;$ Type III SS=93.60; mean square=93.60.

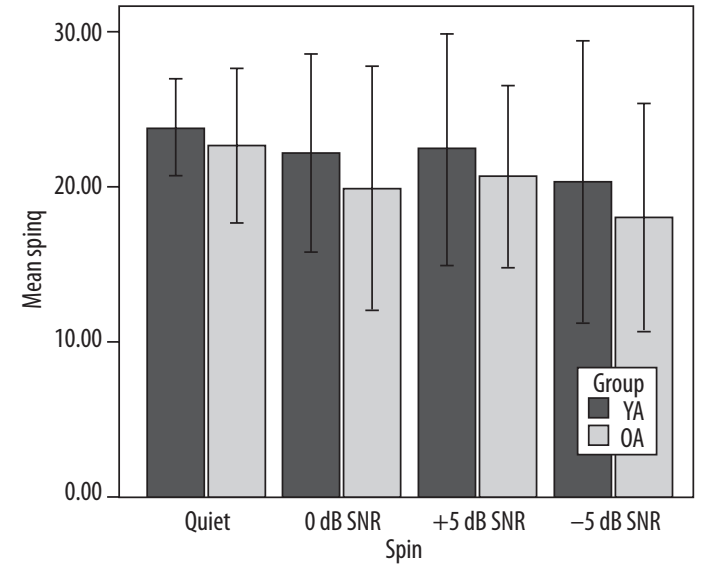

Figure 1. Mean and SD of SPIN in young and middle-aged adults at different SNRs. Error bars: \pm 2 SD

\section{Discussion}

The present study showed a deleterious effect of ageing, so that young adults performed marginally better than middle-aged adults in both TCST as well as in SPIN. Further, as difficulty level was increased the performance became poorer in both the tests.

\section{Effect of age on time-compressed speech test}

The present study showed that young adults outperformed middle-aged individuals in the TCST. The current study also showed significant main effects at different compression ratios (i.e. performance became poorer with increased compression ratio). The above finding is in congruence with findings reported in the literature [13-15,24,31]. Vaughan and Letowski (1997) assessed a method of time compression known as synchronized overlap and used it to increase the rate of speech on young and older populations. They reported that the older group performed poorly compared to the younger group [15]. Similarly, Versfeld and Dreschlerin (2002) evaluated speech intelligibility in young and elderly individuals with and without hearing

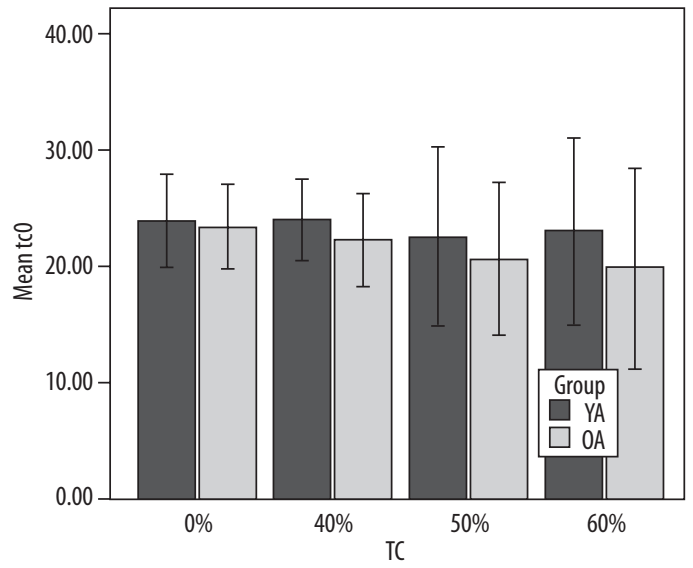

Figure 2. Mean and SD of TCST in young and middle-aged adults at different compression ratios. Error bars: \pm 2 SD

impairment using TCST and SPIN. Overall, elderly listeners performed poorly in comparison with younger listeners with normal hearing. In addition, they also reported good correlation between TCST and speech recognition thresholds obtained in the presence of noise. Apart from age, they also noticed that cognition may also be a contributing factor. If two tests of auditory closure were compared, the SPIN test resembled the natural situation more compared to the TCST [13]. Jafari et al. (2013) also reported a deleterious effect of ageing on a TCST [14]. GordonSalant et al. (2014) also concluded from their study that older listeners are at a much greater disadvantage than younger listeners when listening to natural fast speech [31]. Another study by Prabhu et al. (2015) concluded that as compression ratio increased, speech recognition scores reduced [24]. The findings observed in the present study could be due to inherent properties within the stimulus, extrinsic redundancies which are reduced by the timecompressed speech as the rate of the speech is altered without any distortion in the frequency or intensity of speech. Listeners with intact intrinsic redundancy tend to use their auditory closure skills to infer missing information in time-compressed speech. The poorer temporal 
resolution skill of older individuals reported by previous researchers could also be the reason for the poorer performance in the TCST [32,33].

\section{Effect of age on speech perception in noise}

The present study indicated a deleterious effect (marginally significant) of ageing on speech perception in noise in Kannada. This work also showed significant main effects at different SNR when both the group data was combined (i.e. with increase in SNR, speech perception scores also improved). The finding of the present study is in consonance with previous studies [34-38]. Gordon-Salant and Fitzgibbons (1993) reported age-related factors, other than peripheral hearing loss, contribute to poor speech perception in noise among the elderly [34]. A study by Gordon-Salant and Fitzgibbons (1997) investigated sentence and word perception in noise among older and younger adults [35]. They concluded that under all conditions an effect of age was apparent, with poorer performance by elderly subjects than younger ones [35]. Helfer and Vargo (2009) assessed speech understanding in the presence of steady state noise among younger and middle-aged females. Results showed that the performance of middleaged subjects was significantly poorer than that of younger subjects [36]. Similarly, Wong et al. (2010) also reported younger adults had better speech perception in noise compared to older adults [37]. Meister et al. (2013) investigated speech recognition against different background maskers in older individuals [38]. They showed that even with normal hearing, older listeners performed poorer than younger listeners, which is similar to the present findings. Here we have found that, under adverse listening conditions, the Kannada language is more difficult to understand by middle-aged subjects compared to younger subjects. The present study also showed the need for central auditory processing disorder (CAPD) evaluation and treatment in middle-aged individuals to promote a better quality of life.

\section{Conclusions}

From the above study it can be concluded that ageing has a deleterious effect on time-compressed speech and speech perception in noise, even in individuals with normal hearing. As the level of difficulty increased, performance was poorer in both tests. The deterioration of the central auditory system is implicated as a possible cause of loss of speech understanding under unfavorable listening conditions, even when there is essentially normal peripheral hearing sensitivity. The outcome of the present study leads to a recommendation for CAPD evaluation and management in middle-aged subjects to improve their speech perception under adverse listening conditions and promote a better quality of life.

\section{Acknowledgement}

We acknowledge the Director of AIISH and the HOD of the Department of Audiology. We also thank Mr Manujunath Y. for motivation and support during data collection. We gratefully acknowledge the participants for their patience.

\section{References:}

1. Pedersen KE, Rosenhall U, Moller MB. Longitudinal study of changes in speech perception between 70 and 81 years of age. Audiology, 1991; 30(4): 201-11.

2. Tun PA. Fast noisy speech: Age differences in processing rapid speech with background noise. Psychol Aging, 1998; 13(3): 424-34.

3. Divenyi PL, Haupt KM. Audiological correlates of speech understanding deficits in elderly listeners with mild-to-moderate hearing loss. I. Age and lateral asymmetry effects. Ear Hear, 1997; 18(1): 42-61.

4. Dubno JR, Lee FS, Matthews LJ, Mills JH. Age-related and gender-related changes in monaural speech recognition. J Speech Lang Hear Res, 1997; 40(2): 444-52.

5. Helfer KS, Wilber LA. Hearing loss, aging, and speech perception in reverberation and noise. J Speech Hear Res, 1990; 33(1): 149-55.

6. Cheesman MF, Hepburn D, Armitage JC, Marshall K. Comparison of growth of masking functions and speech discrimination abilities in younger and older adults. Audiology, 1995; 34(6): 321-33.

7. Humes LE, Roberts L. Speech-recognition difficulties of the hearing-impaired elderly: The contributions of audibility. J Speech Hear Res, 1990; 33(4): 726-35.

8. Strouse A, Ashmead DH, Ohde RN, Grantham DW. Temporal processing in the aging auditory system. J Acoust Soc Am, 1998; 104(4): 2385-99.

9. Kumar UA, Sangamanatha AV, Vikas J. Effects of meditation on temporal processing and speech perceptual skills in younger and older adults. Asian J Neurol, 2013; 116(5): 632-40.
10. Schneider BA, Pichora-Fuller MK, Kowalchuk D, Lamb M. Gap detection and the precedence effect in young and old adults. J Acoust Soc Am, 1994; 95(2): 980-91.

11. Snell KB. Age-related changes in temporal gap detection. J Acoust Soc Am, 1997; 101(4): 2214-20.

12. Letowski T, Poch N. Comprehension of time-compressed speech: Effects of age and speech complexity. J Am Acad Audiol, 1996; 7(6): 447-57.

13. Versfeld NJ, Dreschler WA. The relationship between the intelligibility of time-compressed speech and speech in noise in young and elderly listeners. J Acoust Soc Am, 2002; 111: 401-8.

14. Jafari Z, Omidvar S, Jafarloo F. Effects of ageing on speed and temporal resolution of speech stimuli in older adults. Med J Islam Repub Iran, 2013; 27(4): 195-203.

15. Vaughan NE, Letowski T. Effects of age, speech rate, and type of test on temporal auditory processing. J Speech Lang Hear Res, 1997; 40(5): 1192-2000.

16. Wiley TL, Cruickshanks KJ, Nondahl DM, Tweed TS, Klein $\mathrm{R}$, Klein BE. Aging and word recognition in competing messages. J Am Acad Audiol, 1998; 9(3): 191-98.

17. Jerger J, Chmiel R. Factor analytic structure of auditory impairment in elderly persons. J Am Acad Audiol, 1997; 8(4): 269-76.

18. Dubno JR, Horwitz AR, Ahlstrom JB. Benefit of modulated maskers for speech recognition by younger and older adults with normal hearing. J Acoust Soc Am, 2002; 111(6): 2897-907. 
19. Wingfield A, Mccoy SL, Peelle JE, Tun PA, Cox LC. Effects of adult aging and hearing loss on comprehension of rapid speech varying in syntactic complexity. J Am Acad Audiol, 2006; 17(7): 487-97.

20. Engström B, Hillerdal M, Laurell G, Bagger-Sjöbäck D. Selected pathological findings in the human cochlea. Acta Otolaryngol Suppl, 1987; 436: 110-16.

21. Scholtz AW, Appenroth E, Kammen-Jolly K, Scholtz LU, Thumfart WF. Juvenile nasopharyngeal angiofibroma: management and therapy. Laryngoscope, 2001; 111: 681-87.

22. Suzuki T, Nomoto Y, Nakagawa T, Kuwahata N, Ogawa H, Suzuki Y et al. Age-dependent degeneration of the stria vascularis in human cochleae. Laryngoscope, 2006; 116(10): 1846-50.

23. Gordon-Salant S, Fitzgibbons PJ, Friedman SA. Recognition of time-compressed and natural speech with selective temporal enhancements by young and elderly listeners. J Speech Lang Hear Res, 2007; 50(5): 1181-93.

24. Prabhu P, Sujan MJ, Rakshith S. Effect of compression ratio on perception of time compressed phonemically balanced words in Kannada and monosyllables. Audiol Res, 2015; 5(1): 128.

25. Hemakumar G. Acoustic phonetic characteristics of Kannada language. Int J Comp Sci Issue, 2011; 8(2): 332-39.

26. Venkatesh CS. Effect of consonant $/ \mathrm{k} /$ on vowel duration in Kannada. Unpublished Dissertation submitted to University of Mysore; 1995.

27. Savithri SR. Acoustics and psychological correlates of speech. J Acoust Soc Ind, 1989; 17(3): 1-8.

28. Carhart R, Jerger J. Preferred method for clinical determination of pure-tone thresholds. J Speech Hear Disord, 1959; 24(4): $330-35$.
29. Kumar P, Yathiraj A. Time compressed speech test in Kannada for children 7-12 years. Unpublished Dissertation submitted to University of Mysore; 2006.

30. Yathiraj A, Vijaylakshmi CS. Bisyllabic phonemically balanced words in Kannada for children. Unpublished material. All India Institute of Speech and Hearing, Mysore-6.

31. Gordon-Salant S, Zion DJ, Espy-Wilson C. Recognition of time-compressed speech does not predict recognition of natural fast-rate speech by older listeners. J Acoust Soc Am, 2014; 136(4): 268-74.

32. Fostick L, Babkoff H. Temporal and non-temporal processes in the elderly. J Basic Clin Physiol Pharmacol, 2013; 24(3): 191-99.

33. Heinrich A, Alain C, Schneider BA. Within- and betweenchannel gap detection in the human auditory cortex. Neuroreport, 2004; 15(13): 2051-56.

34. Gordon-Salant S, Fitzgibbons PJ. Temporal factors and speech recognition performance in young and elderly listeners. J Speech Hear Res, 1993; 36(6): 1276-85.

35. Gordon-Salant S, Fitzgibbons PJ. Selected cognitive factors and speech recognition performance among young and elderly listeners. J Speech Lang Hear Res, 1997; 40(2): 423-31.

36. Helfer KS, Vargo M. Speech recognition and temporal processing in middle-aged women. J Am Acad Audiol, 2009; 20(4): 264-71.

37. Wong PC, Ettlinger M, Sheppard JP, Gunasekera GM, Dhar S. Neuroanatomical characteristics and speech perception in noise in older adults. Ear Hear, 2010; 31(4): 471-79.

38. Meister H, Schreitmüller S, Grugel L, Beutner D, Walger M, Meister I. Examining speech perception in noise and cognitive functions in the elderly. Am J Audiol, 2013; 22(2): 310-12. 